\section{Um olhar atrás da escrita: o pensamento de Benedito Nunes sobre a Amazônia}

\author{
Maria Stella Faciola Pessôa Guimarães \\ stellapessoa@uol.com.br \\ Dissertação de Mestrado \\ Programa de Pós-Graduação em Desenvolvimento Sustentável \\ do Trópico Úmido \\ Universidade Federal do Pará \\ Belém (PA) 2012
}

\section{A look behind the writting: Benedito Nunes' thinking about the Amazon}

\author{
Maria Stella Faciola Pessôa Guimarães \\ stellapessoa@uol.com.br \\ Master Dissertation \\ Post-Graduate Program in Sustainable Development \\ in the Humid \\ Federal University of Pará \\ Belém (Pará) - Brazil 2012
}

Os trabalhos sobre os intelectuais brasileiros com atividades na Amazônia têm número reduzido e geralmente contêm lacunas, principalmente porque são analisados fora do contexto social, o que contribui para o desconhecimento das ideias desses pensadores. Nesse sentido, esta dissertação opta por metodologia de análise do pensamento de Benedito Nunes, com base em seus textos referentes à região amazônica, relacionando-os aos respectivos contextos de criação. Benedito nasceu e sempre morou em Belém. Tem produção intelectual expressiva. Notabilizou-se, no Brasil e no exterior, atuando nas áreas universitárias de filosofia e de crítica literária. Desenvolveu trabalhos seminais sobre Heidegger, Nietzsche, Guimarães Rosa e Clarice Lispector. Mas o pensador paraense também elaborou ensaios, concedeu entrevistas, escreveu prefácios, participou de debates e apresentou palestras com reflexões sobre história, sociedade e culturas da Amazônia, do Pará e de Belém. Nessa linha, portanto, reflete sobre sua própria região, aspecto que permite identificá-lo com o campo de estudos sobre o pensamento social brasileiro. Este documento analisa onze textos do autor em pauta, devidamente contextualizados, com o objetivo de apresentar uma possibilidade nova de leitura da obra do professor Benedito: como intérprete da Amazônia que usa, para entender a região, o patrimônio do pensamento ocidental que apreendeu com sua esmerada formação. Assim, a dissertação inaugura a inclusão, como objeto de pesquisa das ciências sociais, dessa parte menos revelada do acervo interdisciplinar de Benedito, constituído durante trajetória intelectual singular.
The works about Brazilian intellectuals with activities in Amazon are small numbered and usually have gap, mainly because they are analysed out of social context, which makes it harder to know the ideas of those thinkers. In this sense, this dissertation chooses an analysis methodology of Benedito Nunes' thinking based on his texts concerning the Amazon region and relating them with its respective creation contexts. Benedito Nunes was born and always lived in Belém. He has an expressive intellectual production. He won admiration, in Brazil and abroad, for his engagement in the academic field of philosophy and literary criticism. He wrote seminal papers about Heidegger, Nietzsche, Guimarães Rosa and Clarice Lispector. But the thinker from Pará also wrote essays, granted interviews, wrote forewords, took part in debates and delivered lectures on reflections on history, society and culture from the Amazon, Pará and Belém. In this sense, therefore, he reflects about his own region, and this aspect allows relate him to the study field of Brazilian social thinking. This document analyzes 11 texts by the author in question, duly contextualized, aiming to present a new possibility of reading the works of professor Benedito: as Amazon interpreter that uses, in order to understand the region, the heritage of Western thought that he learned during his accomplished studies. Thus, this dissertation champions the inclusion, as research object of social sciences, of this less revealed part of Benedito's interdisciplinary collection, built during singular intellectual trajectory. 
